\title{
Manganese accumulation and its effects on three tropical aquatic macrophytes: Azolla caroliniana, Salvinia minima and Spirodela polyrhiza
}

Acúmulo e efeitos do manganês em três macrófitas aquáticas tropicais: Azolla caroliniana, Salvinia minima e Spirodela polyrhiza

\author{
Claudineia Lizieri ${ }^{1,2}$, Rosane Aguiar ${ }^{1} \&$ Kacilda Naomi Kuki ${ }^{1}$
}

\begin{abstract}
The phytoremediation technique, which consists of using plants to remove ions, has been increasingly chosen over past decades due to its low-cost technology to mitigate contaminated areas. The aim of this study was to evaluate the potential of the aquatic macrophytes, Azolla caroliniana Willd, Salvinia minima Baker and Spirodela polyrhiza (L.) Schleiden, to accumulate manganese (Mn), an element which, at high concentrations, may be toxic to human populations. The three species accumulated Mn in their tissues and the absorption was independent of the metal concentration in the solution. Spirodela polyrhiza accumulated Mn at higher concentrations of the ion (17.062 $\left.\mathrm{mg} \mathrm{g}^{-1} \mathrm{MS}\right)$, followed by $S$. minima (4.283 $\mathrm{mg} \mathrm{g}^{-1} \mathrm{MS}$ ) and A. caroliniana (1.341 $\left.\mathrm{mg} \mathrm{g}^{-1} \mathrm{MS}\right)$. Manganese excess reduced total chlorophyll content in all three species. Carotenoid content was reduced in $A$. caroliniana $(27.02 \%)$ and S. polyrhiza $(25.34 \%)$. Growth was only significantly reduced (21.34\%) in S. polyrhiza. The species A. caroliniana and S. minima were able to tolerate excess Mn, but were inefficient regarding the accumulation of high concentrations of the metal. High accumulated Mn content in the tissues of S. polyrhiza suggests that the species is able to accumulate this element. Therefore, it has potential for use in phytoremediation and provides a new resource for exploring the Mn accumulation mechanism.
\end{abstract}

Key words: aquatic plants; growth; toxicity; phytoremediation.

\section{Resumo}

A fitorremediação que consiste na utilização de plantas para remoção de íons, tem aumentado nas últimas décadas, tendo em vista a busca por tecnologias de baixo custo para mitigar áreas contaminadas. $\mathrm{O}$ objetivo do presente trabalho foi avaliar o potencial das macrófitas aquáticas: Azolla caroliniana Willd, Salvinia minima Baker (Salviniaceae) e Spirodela polyrhiza (L.) Schleiden (Araceae) em acumular manganês (Mn), um elemento que em concentração elevada pode ser tóxico para população humana. As três espécies acumularam Mn em seus tecidos e a absorção foi dependente da concentração do metal em solução. Spirodela polyrhiza acumulou as concentrações mais elevadas de Mn (17,062 $\left.\mathrm{mg} \mathrm{g}^{-1} \mathrm{MS}\right)$, seguida por $S$. minima $\left(4,283 \mathrm{mg} \mathrm{g}^{-1} \mathrm{MS}\right)$ e A. caroliniana (1,341 $\left.\mathrm{mg} \mathrm{g}^{-1} \mathrm{MS}\right)$. O excesso de Mn causou redução do conteúdo de clorofila total nas três espécies. O conteúdo de carotenóides diminuiu em $A$. caroliniana $(27,02 \%)$ e $S$. polyrhiza $(25,34 \%)$. Apenas em $S$. polyrhiza o crescimento foi reduzido significativamente $(21,34 \%)$. As espécies A. caroliniana e $S$. minima toleraram excessos de $\mathrm{Mn}$, mas foram ineficientes no acúmulo de concentrações elevadas do metal. O elevado conteúdo de Mn acumulado nos tecidos de S. polyrhiza sugere que a espécie possui capacidade para acumular este elemento. Portanto, apresenta potencial para ser utilizada na fitorremediação e oferece um novo recurso para explorar os mecanismos de acúmulo do Mn.

Palavras-chave: plantas aquáticas, crescimento, toxicidade, fitorremediação. 


\section{Introduction}

The presence of heavy metals in aquatic ecosystems causes serious impact on the biological components. As a result, serious disorders on human population health have been observed due to the biomagnification processes and their toxic effects within the food chain (Tavares \& Carvalho 1992; Cabana et al. 1994; Mergler et al. 1994; Doyle et al. 2003).

Manganese (Mn) is an essential trace element in physiological processes, both for plants and animals. However, high concentrations of this metal in the aquatic environment $(>5,200 \mu \mathrm{g} / \mathrm{l})$ can be toxic (Mergler et al. 1994; Boucher \& Watzin 1999; Doyle et al. 2003).

Besides its natural occurrence, the contamination of aquatic ecosystems by $\mathrm{Mn}$ is made worse by human activities, including the disposal of industrial waste. They involve manufacturing processes (metal, paper, and chemical agents), household waste and mining activities (Thornton 1995; Banks et al. 1997).

The National Council for the Environment (CONAMA - Resolution 357, 2005) establishes a total Mn limit of $0.1 \mathrm{mg} / \mathrm{l}$ for class 1 waters (waters that can be used for human consumption after simplified treatment), $0.5 \mathrm{mg} / \mathrm{l}$ for class 3 waters (waters that can be used for human consumption after conventional or advanced treatment) and 1 $\mathrm{mg} / \mathrm{l}$ of dissolved Mn for discharging effluents. However, research has demonstrated that $\mathrm{Mn}$ concentration in waters of mining and mine drainage regions, as well as industrial waste waters, exceed the recommended concentrations (Banks et al. 1997; Sisinno 2003; Guimarães-Silva et al. 2007).

The recovery of areas contaminated by heavy metals can be done through conventional methods such as physical and chemical processes. They may include removing the source of contamination, isolating the contaminated area and/or flocculation (Richter \& Azevedo Netto 1991), which are costly processes. For this reason, phytoremediation has been seen as an attractive, ecologically viable and low-cost technique. Moreover, as it is applied in situ, this technique causes minimal impact to the environment (Chaney et al. 2000; Raskin \& Ensley 2000).

Studies show that water bodies contaminated by metals can benefit from phytoremediation using aquatic macrophytes such as Lemna minor L., Pistia stratiotes L., Spirodela intermedia W. Koch (Araceae) and Ceratophyllum demersum L. (Ceratophyllaceae) (Rai et al. 1995; Miretzky et al. 2004). This process has been very advantageous, as aquatic plants usually show a high rate of vegetative reproduction, rapid growth and are easily handled (Dushenkov et al. 1995; Cunningham \& Ow 1996).

Brazil is favorable for this technology, as this country has auspicious climatic and soil conditions, abundant aquatic environments and high diversity of plant species. However, few studies have reported the effects of the exposure of macrophytes to high concentrations of $\mathrm{Mn}$, which makes it harder to indicate phytoremediation to minimize the impacts caused by this element on aquatic environments.

Research with such an approach must be encouraged, as toxicity by $\mathrm{Mn}$ has become a major environmental problem, especially in the state of Minas Gerais, where Mn occurs in abundance in the matrix rock.

This study aimed to evaluate $\mathrm{Mn}$ accumulation capacity and its effects on total chlorophyll content, carotenoids and growth rate of three tropical free-floating macrophytes: Azolla caroliniana, Salvinia minima and Spirodela polyrhiza. in order to investigate the potential of these species in phytoremediation processes.

\section{Materials and Methods}

The species Azolla caroliniana, Salvinia minima and Spirodela polyrhiza were obtained at the Botanical Garden of the "Universidade Federal de Viçosa (UFV)" and grown in a greenhouse, at "Unidade de Crescimento de Plantas (UCP)" of "Departamento de Biologia Vegetal (DBV/UFV)"। Minas Gerais, Brazil. To adapt to experimental conditions and to biomass obtaining, the macrophytes were grown in Hoagland nutrient solution (Hoagland \& Arnon 1950), with $1 / 5$ ionic strength and $\mathrm{pH} 6.5 \pm 0.5$. The plants were placed on plastic trays in a growth room at $25 \pm 1^{\circ} \mathrm{C}$ temperature, $230 \mu \mathrm{mol}$ of photons $\mathrm{m}^{-2} \mathrm{~s}^{-1}$ illumination and photoperiod of 12 hours of light: dark, during 15 days, to allow daughter plant/propagule uniformity and to assure homogeneity in the plant material used in the treatments, as suggested by Outridge \& Hutchinson (1991). The nutrient solution was replaced every three days.

After the acclimatization period, the experiment began with $1.5 \mathrm{~g}$ A. caroliniana and $S$. polyrhiza fresh mass (FM), and $2.0 \mathrm{~g} \mathrm{~S}$. minima fresh mass, since this species has individuals with greater plant mass in relation to the other species. All plants were placed in polyethylene vessels containing $350 \mathrm{ml}$ of Hoagland solution and increasing Mn doses $(0.05 ; 0.1 ; 0.2 ; 03 ; 0.4 \mathrm{mM})$ in 
the form of $\mathrm{MnCl}_{2} 4 \mathrm{H}_{2} \mathrm{O}$. Control plants were grown in Hoagland solution only. On a daily basis, the $\mathrm{pH}$ of the solutions was measured and, when necessary, corrected to $6.5 \pm 0.5$ with $\mathrm{HCl}(1 \mathrm{M})$ or $\mathrm{NaOH}(1 \mathrm{M})$. The three species were simultaneously tested, in a single experiment, conducted during seven days, in a completely randomized design; five repetitions were made for each treatment, and the plants were kept in the same microclimatic conditions set during the acclimatization period.

On the seventh day after the beginning of the experiment, the plants were removed from the vessels, washed in $1 \%$ nitric solution and rinsed with deionized water. The final weight of sample fresh matter (FM) was recorded, and then the plants were placed in a ventilated greenhouse at $80^{\circ} \mathrm{C}$ to arrive at the final dry weight (DM). The dry matter initial weight for each species was estimated from 10 samples of plants randomly chosen from the same batch as those used for the experiment. The DM data was used in relative growth rate analysis, according to the equation proposed by Hunt (1978).

Total chlorophyll content and carotenoid content for each species were determined from $0.5 \mathrm{~g}$ of fresh plant matter, and $80 \%$ acetone v/v was used as extractant, with $\mathrm{CaCO}_{3}$ (Arnon 1949). The absorbance reading was made at $470 \mathrm{~nm}$ (carotenoids), 646.8 and $663.2 \mathrm{~nm}$ wavelengths (total chlorophyll) in UV Visible spectrophotometer (UVmini-1240, Shimadzu, Japan). From the data obtained, total chlorophyll content and carotenoid content were calculated using the equations proposed by Lichtenthaler (1987).

In order to determine Mn content, dry matter samples underwent wet mineralization with $3 \mathrm{ml}$ of nitro-perchloric mixture $(2: 1, \mathrm{v} / \mathrm{v})$ to $120-140^{\circ} \mathrm{C}$, until organic matter digestion was completed (Tedesco et al. 1995). The mineralized samples were diluted in $25 \mathrm{ml}$ of deionized water, and Mn content determined by atomic absorption spectrometry (AAS $220 \mathrm{FS}$, Varian Australia) at $279.8 \mathrm{~nm}$ wavelength.

The data was analyzed using ANOVA (significance level $p<0,05$ ) and the averages were compared by Tukey testing. The software used for the statistical analysis was SAS (SAS Institute, Cary, NC).

\section{Results}

The macrophytes Azolla caroliniana and Salvinia minima presented visual symptoms of toxicity from the fifth day of Mn exposure. Chlorotic spots were identified on fronds of both species, but only on plants subjected to $0.4 \mathrm{mM}$ of Mn (Fig. 1a-d). In A. caroliniana, these visual symptoms were less intense.

In Spirodela polyrhiza plants, the symptoms were visible from $0.2 \mathrm{mM}$ concentration of $\mathrm{Mn}$, being more pronounced in 0.3 and $0.4 \mathrm{mM}$ concentrations. After the fourth day of exposure to Mn, the leaves showed chlorosis at the basal region, gradually extending to the apical region (Fig. 1e-f).

At the end of the experiment, the relative growth rate of $A$. caroliniana and $S$. minima did not decrease significantly with excess $\mathrm{Mn}$ in the nutrient solution (Fig. 2a-b). However, there was a reduction (16.22\%) of $S$. polyrhiza growth rate beginning at $0.2 \mathrm{mM} \mathrm{Mn}$ concentration. A more pronounced decrease $(21.34 \%)$ was observed in at 0.3 and $0.4 \mathrm{mM} \mathrm{Mn}$ concentrations (Fig. 2c).

Excess $\mathrm{Mn}$ in the solution modified total chlorophyll content in the three macrophytes studied. The changes happened in different ways among the species, as well as among the different treatments (Fig. 3a-c). Total chlorophyll content for A. caroliniana showed no statistical difference between control plants and plants exposed to 0.05 and $0.1 \mathrm{mM}$ concentrations of Mn. Starting at 0.2 $\mathrm{mM}$ concentration, total chlorophyll content was significantly reduced (26.67\%), but did not change at 0.3 and $0.4 \mathrm{mM}$ concentrations of Mn (Fig. 3a). In S. minima plants, there was a $39.69 \%$ reduction of total chlorophyll content, but only in plants exposed to $0.4 \mathrm{mM}$ concentration (Fig. 3b). The decrease in chlorophyll content in S. polyrhiza plants (16.49\%) was statistically different from the control plants starting at $0.2 \mathrm{mM}$ concentration of $\mathrm{Mn}$. A more pronounced decrease (32.98\%) was recorded for 0.3 and $0.4 \mathrm{mM} \mathrm{Mn}$ concentrations (Fig. 3c).

Carotenoid content was significantly reduced in A. caroliniana $(27.02 \%)$ from $0.2 \mathrm{mM}$ concentration of $\mathrm{Mn}$, but was not different at 0.3 and $0.4 \mathrm{mM}$ concentrations (Fig. 4a). Statistically, in $S$. minima, there was no change in carotenoid content between plants exposed to $\mathrm{Mn}$ and control plants (Fig. 4b). In S. polyrhiza, carotenoid content displayed a reduction of $25.34 \%$ in plants exposed to 0.3 and $0.4 \mathrm{mM}$ concentrations of $\mathrm{Mn}$, which were not different among themselves (Fig. 4c).

The Mn content in the DM of plants exposed to different concentrations of that element rose significantly in relation to control plants for the three macrophytes studied. The increase observed was proportional to the concentrations of $\mathrm{Mn}$ in the solution (Fig. 5a-c). 

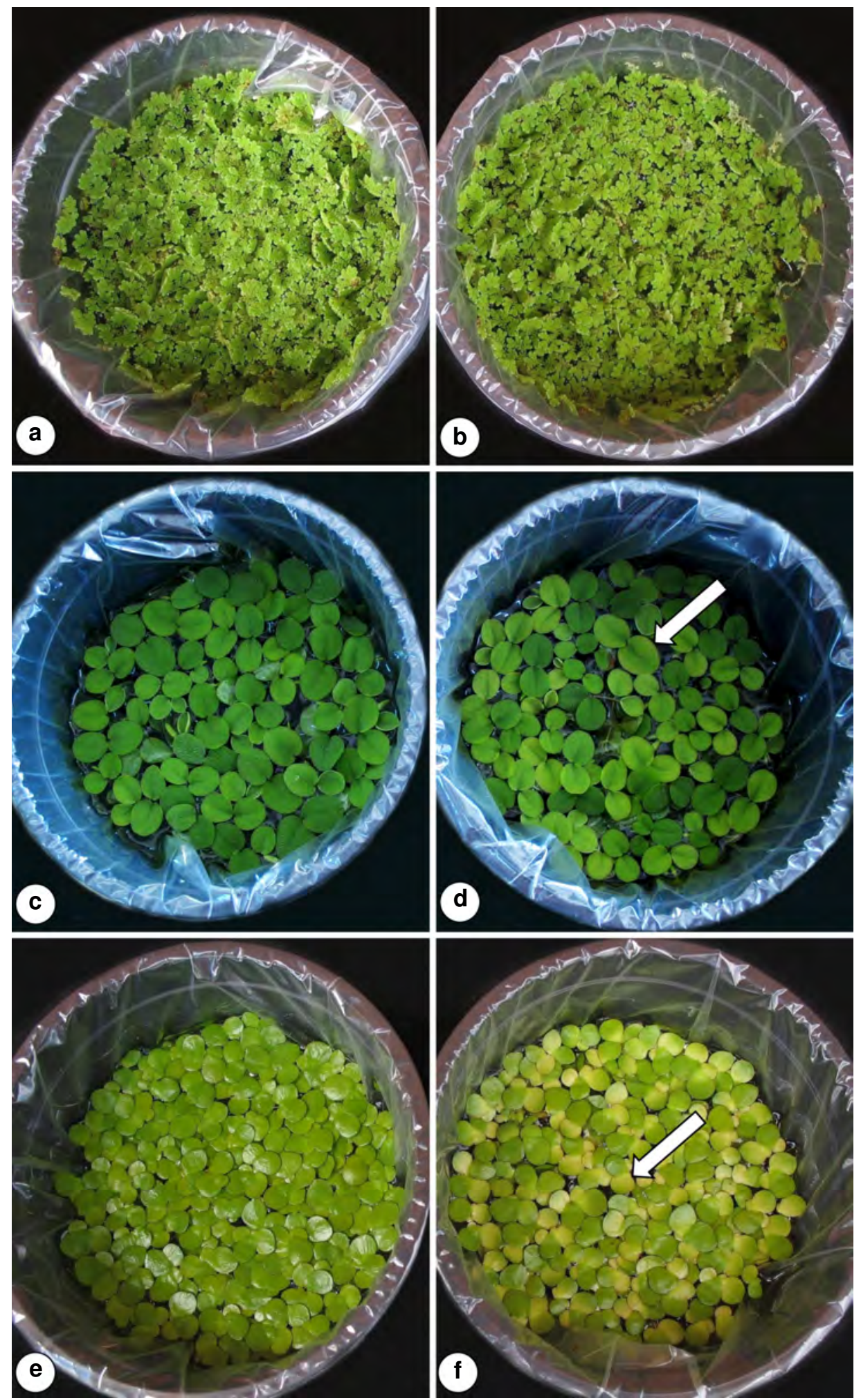

Figure 1 - Characterization of the visual symptoms of aquatic macrophytes - a,c, e. control plants; b, d, f. plants exposed to $0.4 \mathrm{mM}$ Mn; a-b. Azolla caroliniana; c-d. Salvinia minima, d. overview of plants exposed to Mn, showing fronds chlorosis (arrow); e-f. Spirodela polyrhiza; f. overview of plant exposed to Mn showing leaves chlorosis (arrow). 

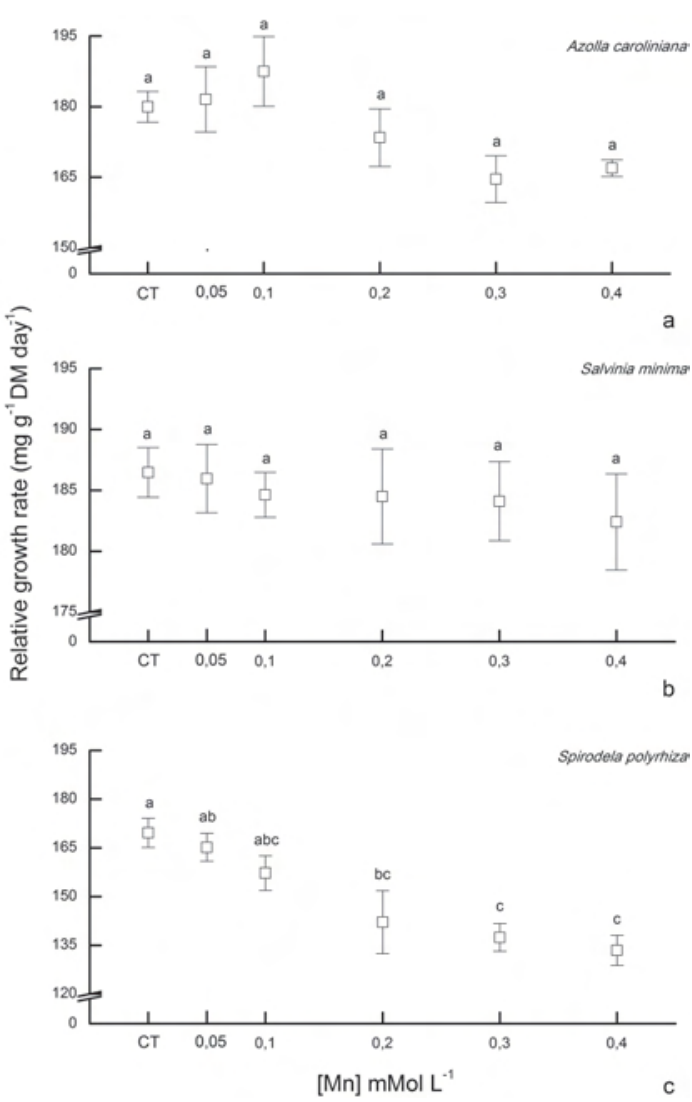

Figure 2 - Relative Growth Rate for Azolla caroliniana (a), Salvinia minima (b) and Spirodela polyrhiza (c), for different concentrations of Mn. Significant differences are indicated by different letters $(\mathrm{a}-\mathrm{c})$ above the bars $(P<0,05)$. CT $=$ Control.

However, Mn accumulation for $A$. caroliniana did not show statistical differences among treatments $0.05 ; 0.1$ and $0.2 \mathrm{mM}$, but rose in 0.3 and $0.4 \mathrm{mM}$ concentrations (Fig. 5a). In S. minima, accumulated $\mathrm{Mn}$ was similar between treatments 0.05 and $0.1 \mathrm{mM}$, increasing in treatments $0.2 ; 0.3$ and 0.4 $\mathrm{mM}$, yet, the latter concentrations were not statistically different between themselves (Fig. 5b). The content of accumulated $\mathrm{Mn}$ in $S$. polyrhiza increased proportionally in relation to its concentration in solution, and showed significant differences among all Mn concentrations (Fig. 5c).

\section{Discussion}

Knowledge of plant response to $\mathrm{Mn}$ accumulation is limited. Literature provides some descriptions for woody or shrubby species, and mostly for vascular plants with economic value (Memon \& Yatazawa 1980; Caldwell 1998; Fecht-Christoffers et al.
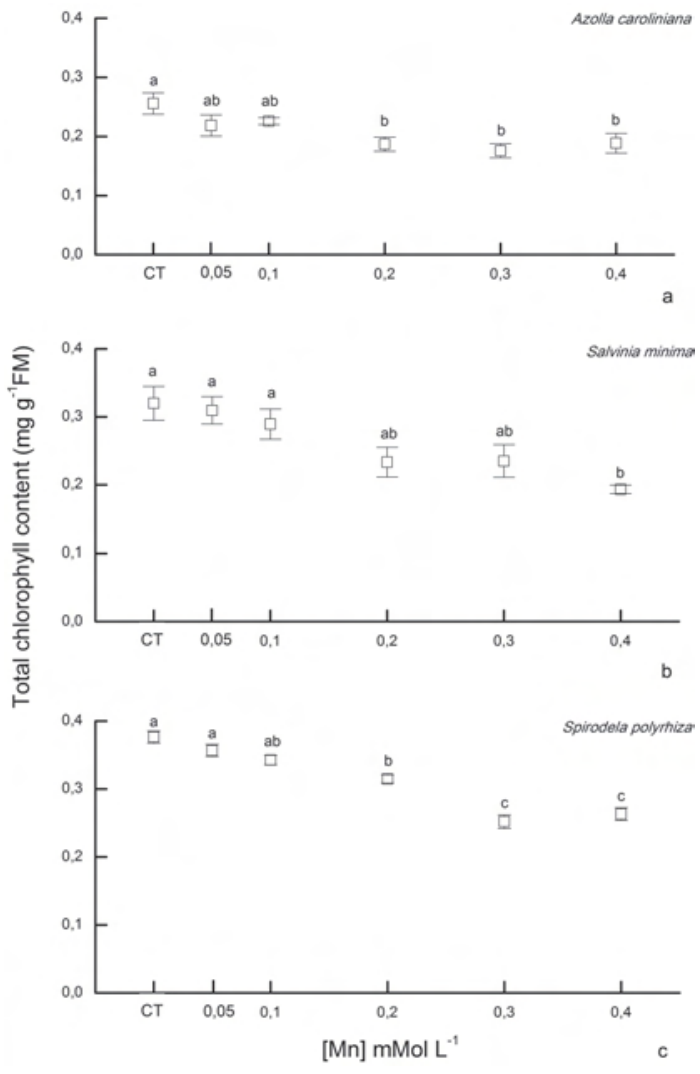

Figure 3 - Total chlorophyll content in Azolla caroliniana (a), Salvinia minima (b) and Spirodela polyrhiza (c), for different concentrations of Mn. Significant differences are indicated by different letters (a-c) above the bars $(P<0,05)$. CT $=$ Control.

2003; Fernando et al. 2006). However, information on aquatic macrophytes is scarce.

In this study, the aquatic macrophytes Azolla caroliniana, Salvinia minima and Spirodela polyrhiza accumulate $M n$ in their tissues. Yet, these species can be distinguished for their capacity to accumulate the element.

Azolla caroliniana showed low values $(0.080$ $-1.341 \mathrm{mg} \mathrm{g}^{-1} \mathrm{DM}$ ) of accumulated Mn in relation to the other two species. Studies by Santos (2006) and Guimarães (2006) assessed the potential of $A$. caroliniana to accumulate Arsenic (As) and found that this species also presented low capacity to accumulate the metalloid in relation to Lemna gibba L. and S. minima plants. Presumably, A. caroliniana has an exclusion mechanism in response to metal excess in solution, including $\mathrm{Mn}$, as well as As. Thus, by reducing metal accumulation in the tissues, it reduces the chance of plant toxicity, 

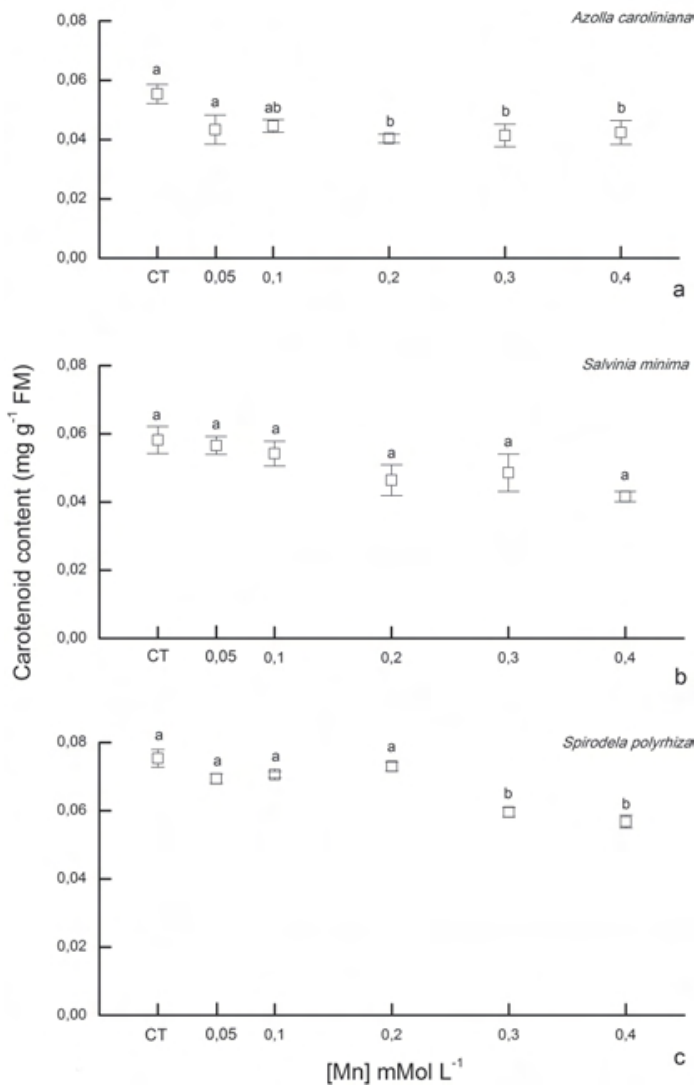

Figure 4 - Content of carotenoids in Azolla caroliniana (a), Salvinia minima (b) and Spirodela polyrhiza (c), for different concentrations of Mn. Significant differences are indicated by different letters $(\mathrm{a}-\mathrm{b})$ above the bars $(P$ $<0,05)$. CT $=$ Control.

granting more tolerance to the plant (Reichman 2002). This fact was verified in the present study when A. caroliniana plants exposed to the highest concentration of $\mathrm{Mn}$ showed less visible symptomatology than the other tested species.

Salvinia minima showed intermediate values (0.097 - $\left.4.283 \mathrm{mg} \mathrm{g}^{-1} \mathrm{DM}\right)$ for $\mathrm{Mn}$ accumulation in relation to A. caroliniana and $S$. polyrhiza. This data provides positive indications for the use of this species to mitigate water bodies contaminated with Mn. The accumulated Mn values and the fact that these plants did not have their growth affected even when exposed to $0.4 \mathrm{mM}$ of $\mathrm{Mn}$ are promising results, since aquatic macrophytes used in any treatment system must primarily comply with two important criteria: pollutant absorption capacity and high growth rate (Visoottiviseth et al. 2002).

The implementation of this genus (Salvinia) in metal removal programs has been recommended
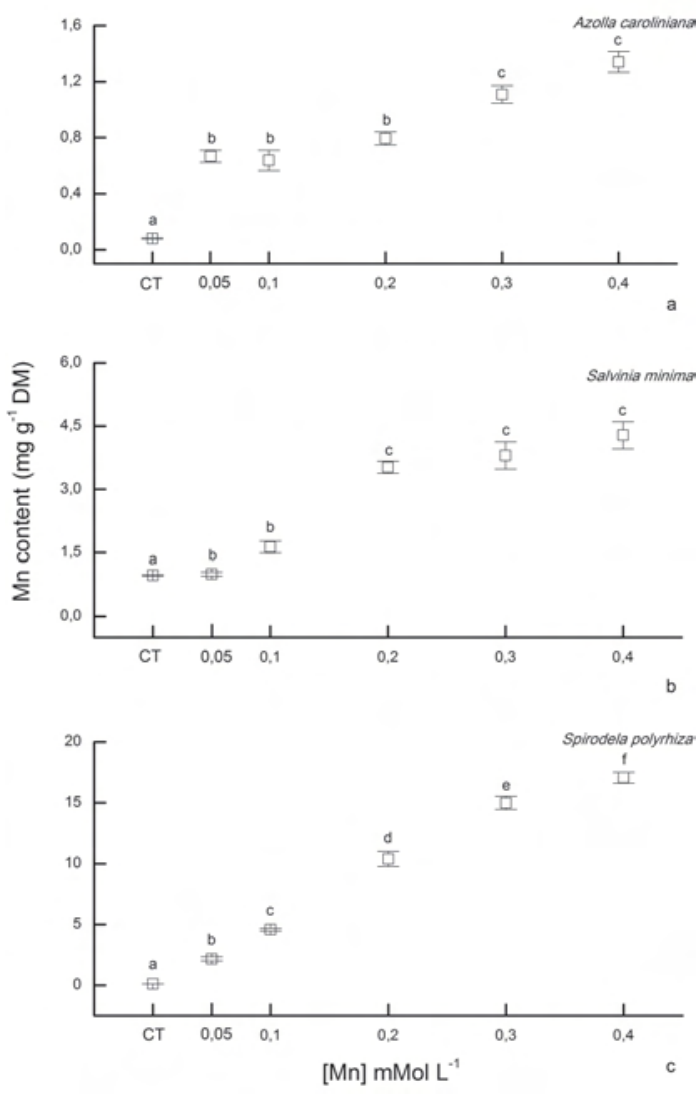

Figure 5 - Accumulation of Mn in plants of Azolla caroliniana (a), Salvinia minima (b) and Spirodela polyrhiza (c) for different metal concentrations. Significant differences are indicated by different letters (a-f) above the bars $(P<0,05)$. CT $=$ Control.

by some researchers (Olguín et al. 2002; Hoffmann et al. 2004; Soares et al. 2008). Accumulation and toxic-effect responses were reported for that species in stress situations with Cadmium $(\mathrm{Cd})$ (Olguín et al. 2002), Lead (Pb) (Hoffmann et al. 2004), Chrome (Cr) (Nichols et al. 2000), Arsenic (As) and atrazine (Guimarães 2006). However, information in the literature on S. minima potential for absorbing and accumulating $\mathrm{Mn}$ is scarce, and the results of the present study are pioneer.

Spirodela polyrhiza species accumulated high concentrations of $\mathrm{Mn}\left(17.062 \mathrm{mg} \mathrm{g}^{-1} \mathrm{DM}\right)$ in plant tissues. Sinha et al. (1994) also observed the capacity of that species to accumulate Mn. S. polyrhiza potential to accumulate different contaminants has been reported by many authors (Tripathi \& Chandra 1991; Sinha et al. 1994; Rai et al. 1995; Noraho \& Gaur 1996), and the use of that species for phytoremediation has been considered 
very promising. Rai et al. (1995) observed that $S$. polyrhiza was able to reduce the copper level in $90 \%$ in a solution. Sinha et al. (1994) reported that S. polyrhiza accumulated significant amounts of iron $(71 \mu \mathrm{mol})$, this capacity being similar to the data obtained in this study for Mn.

The main characteristic required for the use of plant species in phytoremediation technology is pollutant bioaccumulation, which is related to high productivity of plant biomass (Vissottiviseth et al.2002). However, excessive accumulation of metals in plants usually leads to changes in physiological and biochemical processes, which can be damaging to plant metabolism. This affects the growth and development of the plant (Barceló \& Poschenrieder 1990; Oliveira et al. 2001), and therefore can make the use of plants in phytoremediation technology impossible.

In this study, we found that $\mathrm{Mn}$ accumulation in plants exposed to $0.2-0.4 \mathrm{mM}$ concentrations is associated with toxicity symptoms in all three species studied; yet, such events displayed different characteristics. A reduction of total chlorophyll content was observed in $A$. caroliniana, S. minima and S. polyrhiza. The reduction of chlorophyll content in plants exposed to Mn has been associated, at least partially, to the fact that Mn leads to iron deficiency in plant tissues, an element necessary for chlorophyll synthesis (Csatorday et al. 1984; Beale 1999). Another possibility would be the fact that Mn can replace the $\mathrm{Mg}$ ion in the chlorophyll molecule, and so impede the metabolic function of the molecule (Mukaopadhyay \& Sharma 1991; Hauck et al. 2002).

The decrease in carotenoid content for $S$. polyrhiza and A. caroliniana reinforce the results found by Caldwell (1998) and Asrar et al. (2005) for different terrestrial plants exposed to Mn excess. Carotenoid reduction was proven to be related to an increase in Mn content in thylakoids, presumably interfering with stacking and pigment content in the chloroplasts (Lidon et al. 2004). This hypothesis could explain the carotenoid-content reduction observed in A. caroliniana and $S$. polyrhiza after the increase in Mn concentrations ( 0.2 to $0.4 \mathrm{mM}$ ) in solution, which was followed by a Mn content increase in macrophyte dry matter.

The fact that vegetative growth was not significantly affected in A. caroliniana and $S$. minima, even in the presence of high concentrations of Mn, may be due to lower Mn content accumulated in macrophyte tissues. On the other hand, the reduction in $S$. polyrhiza growth rate after exposure to Mn excess may have been a consequence of the high concentration of the element in plant tissues, leading to nutritional imbalance, and also to a decrease in total chlorophyll content observed in the plants, since that pigment is substantial to the process of carbon conversion to biomass.

Responses to $\mathrm{Mn}$ accumulation among the three species studied are probably related to differences in absorption and $\mathrm{Mn}$ content accumulated in the plant tissues, which grants different tolerance patters to the element. Results show that $A$. caroliniana and S. minima tolerate Mn excess in solution. However, the plants were not effective in accumulating high amounts of the metal in their tissues.

Further studies must be conducted, including more refined analysis, with the purpose of enhancing knowledge about aquatic plants response to $\mathrm{Mn}$ excess. The combined and/or alternate use of the species studied could be a promising practice capable of aiding $\mathrm{Mn}$ sequestration in contaminated aquatic environments, especially those where metal concentrations are not too high.

\section{References}

Arnon, D.I. 1949. Copper enzymes in isolated chloroplast polyphenol-oxidases in Beta vulgaris. Plant Physiology 24: 1-15.

Asrar, Z.; Khavari-Nejad, R.A. \& Heidari, H. 2005. Excess manganese effects on pigments of Mentha spicata at flowering stage. Archives of Agronomy and Soil Science 51: 101-107.

Banks, D.; Younger, P.L.; Arnesen, R.T.; Iversen, E.R. \& Banks, S.B. 1997. Minewater chemistry: the good, the bad and the ugly. Environmental Geology 32: 157-174.

Barceló, J. \& Poschenrieder, C. 1990. Plant water relations as affected by heavy metal stress: a review. Journal of Plant Nutrition 13: 1-37.

Beale, S.I. 1999. Enzymes of chlorophyll biosynthesis. Photosynthesis Research 60: 43-73.

Boucher, A.M. \& Watzin, M.C. 1999. Toxicity identification evaluation of metal-contaminated sediments using an artificial pore-water containing dissolved organic carbons. Environmental Toxicology and Chemistry 18: 509-518.

Cabana, G.; Tremblay, A.; Kaff, J. \& Rasmussen, J.B. 1994. Pelagic food chain structure in Ontario Lakes: a determinant of mercury levels in lake trout (Salvelinus namaycush). Canadian Journal of Fisheries and Aquatic Sciences 51: 381-389.

Caldwell, C.R. 1998. Effect of elevated manganese on the ultraviolet and blue light-absorbing compounds of cucumber cotyledon and leaf tissues. Journal of Plant Nutrition 21: 435-445. 
Csatorday, K.; Gombos, Z. \& Szalontai, B. 1984. Mn²+ and $\mathrm{Co}^{2+}$ toxicity in chlorophyll biosynthesis. Proceedings of the National Academy of Sciences 81: 476-478.

Chaney, R.L.; Li, Y.M.; Brown, S.L.; Homer, F.A.; Malik, M.; Angle, J.S.; Baker, A.J.M.; Reeves, R.D. \& Chin, M. 2000. Improving metal hyperaccumulator wild plants to develop commercial phytoextraction systems: approaches and progress. In: Terry, N. \& Bañuelos, G.S. (ed.). Phytoremediation of contaminated soil and water. Lewis Publishers, Boca Raton. Pp.129-158.

CONAMA - Conselho Nacional do Meio Ambiente. Resoluçãon ${ }^{\circ} 357$, de 17 de março de 2005. Disponível em <http://www.crq4.org.br/downloads/resolucao 357.pdf>. Acesso em 22 Fev 2009.

Cunningham, S. \& Ow, D. W. 1996. Promises and prospects of phytoremediation. Plant Physiology 110: 715-719.

Doyle, C.J.; Pablo, F.; Lim, R.P. \& Hyne, R.V. 2003. Assessment of metal toxicity in sediment pore water from lake Macquarie, Australia. Archives of Environmental Contamination and Toxicology 44: 343-350.

Dushenkov, V.; Kumar, P.B.A.N.; Motto, H. \& Raskin, I. 1995. Rizofiltration: The use of plants to remove heavy metals from aqueous streams. Environmental Science \& Technology 29: 1239-1245.

Fecht-Christoffers, M.M.; Maier, P. \& Horst, W.J. 2003. Apoplastic peroxidases and ascorbate are involved in manganese toxicity and tolerance of Vigna unguiculata. Physiologia Plantarum 177: 237-244.

Fernando, D.R.; Bakkaus, E.J.; Perrier, N.; Baker, A.J.M.; Woodrow, I.E.; Batianoff, G.N. \& Collins, R,N. 2006. Manganese accumulation in the leaf mesophyll of four tree species: a PIXE/EDAX localization study. New Phytologist 171: 751-758.

Guimarães, F.P. 2006. Potencial de macrofilas para remoção de arsênio e atrazine em solução aquosa. Dissertação de Mestrado. Universidade Federal de Viçosa, Viçosa. 71p.

Guimarães-Silva, A.K.; Machado, D.A.; Nalini, H.A. \& Lena, J.C. 2007. A qualidade das águas na região dos garimpos de topázio imperial na sub-bacia do rio da Ponte, Ouro Preto-MG. Revista Escola de Minas 60: 603-611.

Hauck, M.; Mulack, C. \& Paul, A. 2002. Manganese uptake in the epiphytic lichens Hypogymnia physodes and Lecanora conizaeoides. Environmental and Experimental Botany 48: 107-117.

Hoagland, D.R. \& Arnon, D.I. 1950. The water-culture method for growing plants without soil. Circular 347. California Agricultural Experiment Station, Berkeley. 37p.

Hoffmann, T. \& Kutter, C., Santamaría, J. 2004. Capacity of Salvinia minima Baker to tolerate and accumulate As and $\mathrm{Pb}$. Engineering in Life Sciences 4: 61-65.
Hunt, R. 1978. Plant growth analysis. Edward Arnold Publishers, London. 67p.

Lichtenthaler, H.K. 1987. Chlorophylls and carotenoids: Pigments of photosynthetic biomembranes. Methods in Enzimology 148: 350-382.

Lidon, F.C.; Barreiro, M.G. \& Ramalho, J.C. 2004. Manganese accumulation in rice: implications for photosynthetic functioning. Journal of Plant Physiology 161: 1235-1244.

Memon, A.R. \& Yatazawa, M. 1980. Distribution of manganese in leaf tissues of manganese accumulator: Acanthopanax sciadophylliodes as revealed by electron probe X-ray microanalyzer. Journal of Plant Nutrition 2: 457-476.

Mergler, D.; Huel, G.; Bowler, R.; Iregren, A.; Belanger, S.; Baldwin, M.; Tardif, R.; Smargiassi, A. \& Martin, L. 1994. Nervous system dysfunction among workers with long-term exposure to manganese. Environmental Research 64: 151-180.

Miretzky, P.; Saralegui, A. \& Cirelli, A.F. 2004. Aquatic macrophytes potential for the simultaneous removal of heavy metals (Buenos Aires, Argentina). Chemosphere 57: 997-1005.

Mukaopadhyay, M.J. \& Sharma, A. 1991. Manganese in cell metabolism of higher plants. Botanical Review 51: 117-149.

Noraho, N. \& Gaur, J.P. 1996. Cadmium adsorption and intracellular uptake by two macrophytes, Azolla pinnata and Spirodela polyrhiza. Archiv für Hydrobiologie 136: 135-144.

Nichols, P.B.; Couch, J.D. \& Al Hamdani, S.H. 2000. Selected physiological responses of Salvinia minima to different chromium concentrations. Aquatic Botany 68: 313-319.

Olguín, E.J.; Hernández, E.; Ramos, I. 2002. The effect of both different light conditions and the $\mathrm{pH}$ value on the capacity of Salvinia minima Baker for removing cadmium, lead and chromium. Acta Biotechnologica 22: 121-131.

Oliveira, J.A.; Cambraia, J.; Cano, M.A.O. \& Jordão, C.P. 2001. Absorção e acúmulo de cádmio e seus efeitos sobre o crescimento relativo de plantas de aguapé e de salvínia. Revista Brasileira de Fisiologia Vegetal 13: 329-341.

Outridge, P.M.; Hutchinson, T.C. 1991. Induction of cadmium tolerance by acclimation transferred between ramets of the clonal fern Salvinia minima Baker. New Phytologist 117: 597-605.

Rai, U.N.; Sinha, S.; Tripathi, R.D. \& Chandra, P. 1995. Wastewater treatability potential of some aquatic macrophytes: Removal of heavy metals. Ecological Engineering 5: 5-12.

Raskin, I. \& Ensley, B.D. 2000. Phytoremediation of toxic metals: using plants to clean up the environment. John Wiley and Sons, New York. 303p. 
Reichman, S.M. 2002. The responses of plants to metal toxicity: a review focusing on copper, manganese and zinc. Australian Minerals and Energy Environment Foundation, Melbourne. Pp. 14-59.

Richter, C. A. \& Azevedo Netto, J. M. 1991. Tratamento de água: tecnologia atualizada. Edgard Blücher, São Paulo. 332p.

Santos, G.V. 2006. Crescimento e respostas antioxidantes de macrófitas aquáticas submetidas ao arsênio. Dissertação de Mestrado. Universidade Federal de Viçosa, Viçosa. 45p.

Sisinno, C.L.S. 2003. Disposição em aterros controlados de resíduos sólidos industriais não-inertes: avaliação dos componentes tóxicos e implicações para o ambiente e para a saúde humana. Cadernos de Saúde Pública 19: 369-374.

Sinha, S.; Rai, U.N. \& Chandra, P. 1994. Accumulation and toxicity of iron manganese in Spirodela polrrhiza (L.) Schleiden. Environmental Contamination Toxicology 53: 610-617.

Soares, D.C.F.; Oliveira, E.F.; Silva, G.D.F.; Duarte, L.P.; Pott, V.J. \& Vieira Filho, S.A. 2008. Salvinia auriculata: Aquatic bioindicator studied by instrumental neutron activation analysis (INAA). Applied Radiation and Isotopes 66: 561-564.

Tavares, T.M. \& Caravalho, F.M. 1992. Avaliação de exposição de populações humanas a metais pesados no ambiente: exemplo do Recôncavo Baiano. Química Nova 15: 147-154.

Tedesco, M.J.; Gianello, C.; Bissani, C.A.; Bohnen, H. \& Volkweiss, S.J. 1995. Análise de solo, plantas e outros materiais. UFRGS, Porto Alegre. 174p.

Thornton, I. 1995. Metals in the global environment. International Council on Metal and the Evironment, Ottawa. 53p.

Tripathi, R.D. \& Chandra, P. 1991. Chromium uptake by Spirodela polyrrhiza (L.) Schleiden in relation to metal chelators and $\mathrm{pH}$. Environmental Contamination and Toxicology 447: 767-769.

Vissottiviseth, P.; Francesconi, B. \& Ridokchana, W. 2002. The potencial of Thai indigenous plant species for the phytoremediation of arsenic contaminated land. Environmental Pollution 118: 453-461. 